\title{
Stereotypical National Characterizations in the Europe of Shakespeare's Day
}

Pauline Blanc

\section{(2) OpenEdition \\ 1 Journals}

\section{Édition électronique}

URL : http://journals.openedition.org/shakespeare/738

DOI : 10.4000/shakespeare.738

ISSN : 2271-6424

Éditeur

Société Française Shakespeare

\section{Édition imprimée}

Date de publication : 1 novembre 2005

Pagination : 27-38

ISBN : 2-9521475-1-5

\section{Référence électronique}

Pauline Blanc, «Stereotypical National Characterizations in the Europe of Shakespeare's Day », Actes des congrès de la Société française Shakespeare [En ligne], 22 | 2005, mis en ligne le 01 janvier 2007, consulté le 10 décembre 2020. URL : http://journals.openedition.org/shakespeare/738 ; DOI : https:// doi.org/10.4000/shakespeare.738 


\section{Shakespeare et l'Europe de la Renaissance}

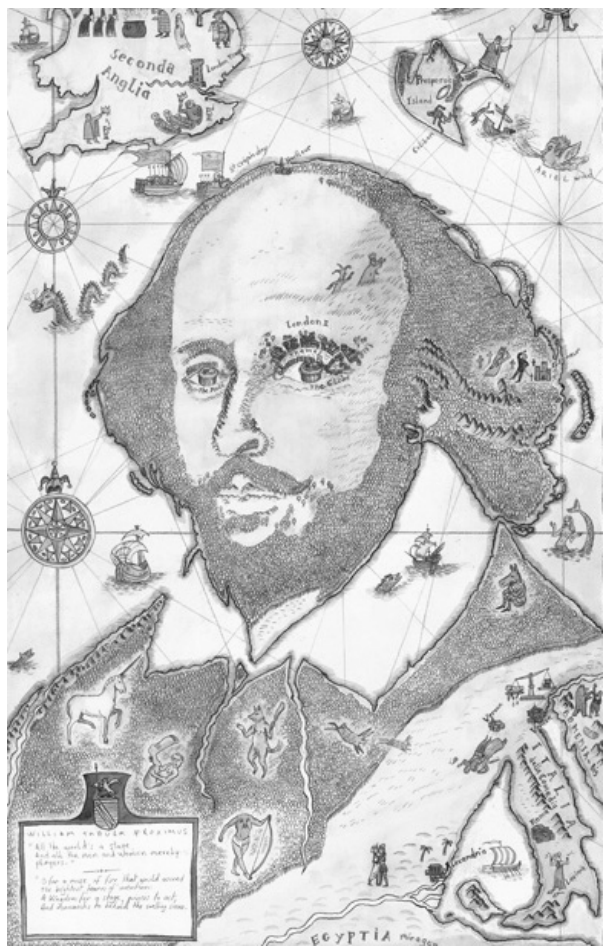

a ctes du Congrès

organisé par la

SOCIÉTÉ FRANÇAISE SHAKESPEARE

les 11,12 et 13 mars 2004

textes réunis par

Pierre KAPITANIAK

sous la direction de

Yves PEYRÉ 


\title{
COMITÉ SCIENTIFIQUE :
}

\author{
Margaret Jones-Davis \\ Jean-Marie Maguin \\ Yves Peyré \\ Pierre Kapitaniak
}

COUVERTURE :

Edouard Lekston, William Tabula Proximus, 2004

conception graphique et logo

Pierre Kapitaniak

CC 2004 Société Française Shakespeare

Institut du Monde Anglophone

Université de Paris III - Sorbonne Nouvelle

http:// univ-montp3.fr/SFS/

5 rue de l’École de Médecine

75006 Paris

ISBN 2-952 1475-1-5

Tous droits de traduction, de reproduction et d'adaptation réservés pour tous les pays 


\title{
S TEREOTYPiCAL N ATIONAL CHARACTERIZATIONS IN THE EUROPE OF SHAKESPEARE'S D AY
}

\author{
Pauline BLANC
}

\begin{abstract}
This paper seeks to explore some of the origins and reasons for certain stereotyped attributions that Shakespeare and his contemporaries lent their European neighbours. Taking as a starting-point the list that Portia runs off in her discussion of her suitors in The Merchant of Venice (1596), the focus is gradually narrowed down to stereotypes of the Italians and of the Spanish in an age when increased travel and reading seems to have fed prejudices rather than to have opened minds.
\end{abstract}

La teneur de l'article va consister à explorer les origines de certains attributs stéréotypés que Shakespeare et ses contemporains prêtaient à leurs voisins européens. La liste de ses prétendants que Portia passe en revue dans The Merchant of Venice (1596) est prise comme point de départ pour ensuite orienter notre exploitation vers une étude plus spécifique de l'Italien et de l'Espagnol. $\dot{A}$ une époque où les habitants d'un pays apprenaient à connaître ceux des autres pays à travers les voyages et la lecture, il semblerait que l'information alimentait plus les préjugés qu'elle n'ouvrait les esprits.

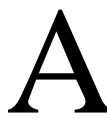

ny discussion concerning the Europe of Shakespeare's day begs the question as to what Europe represented to Renaissance man. As the historian John Hale reminds us, ${ }^{1}$ scholars had known throughout the Middle Ages that they lived in a continent called by classical geographers "Europe" to distinguish it from Africa and Asia, the other land masses partly known to them, but the majority of people who lived in Europe were illiterate and had never heard of the word. Any knowledge of a world beyond their national borders derived from stories of martyrs, missionaries, crusaders or preachers. The clergy taught them that they were Christians, forming part of a continent, which had been chosen by divine providence to harbour the true faith: Christendom.

The notion of Christendom was secularised to that of Europe, a word which was colloquially vague, even if it became part of common linguistic usage in the second half of the fifteenth century. Europe adopted Ovid's story of the abduction of Europa by Jove as its founding myth but, whether Christianised or demythologised, there is no hint

\footnotetext{
${ }^{1}$ For the basic historical background to this study of stereotypes I am indebted to John Hale's knowledgeable account of Europe from the fall of Constantinople to the start of the Thirty Years War: John Hale, The Civilization of Europe in the Renaissance (London: Fontana Press, 1993). I am equally indebted to Peter Burke's portrait of the Renaissance which I have only been able to consult in translation: Peter Burke, La Renaissance européenne, trans. Paul Chemla (Paris: Éditions du Seuil, 2000).
} 
that Europeans thought of themselves as owing anything material to this "Europa." Even the great cartographer Abraham Ortelius wondered why the continent should be called Europe. He seems to have forgotten Herodotus's interpretation of the myth: for the latter, Europe was Greece and all other lands were peopled with barbarians. In the sixteenth century a slightly different world view came into being: Europe was personified as a "dirigiste" figure conveying the idea of political and commercial superiority over the godless or the erroneous believers who peopled the other known continents (Asia, Africa and America).

Through increased travel and reading, people of one country came to learn more about those of other countries within the cartographic frame of this superior-minded continent. Information may open minds, but it will also feed prejudices and we find superimposed on the objective map of Europe a subjective map of stereotyped national characters in the writings of well-educated men, either intended as parodies or as serious observations. This paper seeks to explore some of the origins and reasons of certain stereotyped attributions that can be found in the works of Shakespeare and his contemporaries.

An Elizabethan audience in 1596 would have been familiar with the playful, xenophobic stereotyping that Portia indulges in when discussing her suitors. The Neapolitan prince loves horses too much; the County Palatine, being of the Calvinist branch of Protestantism, is "full of unmannerly sadness" (I.ii.49); ${ }^{3}$ God made Monsieur le Bon, so, in spite of his effeminate ways, it is implied, he may "pass for a man" (I.ii.53); the English Falconbridge "hath neither Latin, French nor Italian" (I.ii.66-67) but has evidently travelled abroad and adopted continental fashions and manners to such a reprehensible extent that he has become the target of much ridicule and scorn from his fellow countrymen. The young German suitor is predictably reified as "a sponge" (I.ii.95) for Rhenish wine, and the Scottish lord, whose abortive negotiations with Catholic France come under fire, is quickly dismissed as an unsuitable candidate for the lady's hand. Portia's

\footnotetext{
2 J. Hale, op. cit., 12.

${ }^{3}$ All quotations from The Merchant of Venice are from the Arden edition, ed. John Russell Brown (London: Methuen, 1964).
} 
allusions to the Prince of Morocco are tainted with the usual racial prejudice associated with blackness, that Renaissance emblem of barbaric alterity, that demonised other in its paradigmatic form, a black face - "the complexion of a devil" (I.i.124). The next-to-last of the suitors, the haughty Spanish Prince of Arragon, is dubbed a "deliberate fool" (II.ix.80) after the lesson in humility he is given through the dramatist's device of the caskets.

Portia's glib generalizations are dashed off in an automatic manner, reminding the spectator/reader of the etymological origin of the stereotype: a component of typography which could be easily reproduced. Like clichés, symbols, and slogans, stereotypes are easily assimilated and repeated. Portia's xenophobic name-calling forms part of the collective imagination and, providing dramatic economy, enables Shakespeare to concentrate on three of the suitors, to contrast and compare the essential human values underlying the appearances of the pretenders to the hand of the lady of Belmont. The yardstick with which they are measured is given by Nerissa who praises Bassanio for being "a scholar and a soldier" (I.ii.109), that is to say a Venetian endowed with the two graces considered complementary in the Renaissance courtier. William Thomas's History of Italy (1549) provides the gloss to Nerissa's allusion in its approval of the Italian students who "studie more for knowledge and pleasure, than for curiositee or luker," and who are said to be "the greatest doers of tilting and feats of arms."4

All the stereotypes that Portia articulates can be found in contemporary travelogues. Those which concern the intrinsic character of various nationalities circulated widely in early modern England and on the continent. They share common features in that they present both subjective understanding and misunderstanding of the culture observed. Travelogues being texts that are constructed after the events described have taken place, they evaluate experiences in terms of the writer's identity and familiar contexts. Furthermore, writings and opinions of other travellers are often included instead of first-hand observation. Accuracy is therefore limited and the travelogues reveal much about the cultural assumptions of the writers themselves. Portia's stereotypes consist in re-presentations of the nationalities re-

\footnotetext{
${ }^{4}$ John Russell Brown, op. cit., 20, n. 109.
} 
viewed in Shakespeare's re-working of the news and stories related by travellers.

Strikingly, authors from different countries often hold the same opinions about the national characteristics under consideration. The Italian writer Giovanni Botero, the English Fynes Moryson, and Shakespeare all report a tendency to drunkenness among Germans. In George Sandy's A Relation of a Journey (1615) we find allusions to the Neapolitan gentry whom he says "delight much in great horses, where upon they prance continually throughout the streets" (4.257). ${ }^{5}$ In Botero's Relations of the Most Famous Kingdoms (1608) we read that "the Spanish nation by nature is proud, yet base, and such as careth not though they be hated, so they may be feared."6 In An Itinerary (1617), Fynes Moryson describes Frederick IV, Palatine and Elector, brought up in the Calvinist religion, as leading a very frugal life. In addition, Moryson refers to the uncouthness and drunkenness of the Germans and compares the Italians to the Turks in the following manner:

For fleshly lusts, the very Turks (whose carnal religion alloweth them) are not so much transported therewith, as the Italians are (in their restraint of civil laws and the dreadful law of God). A man of these Northerly parts can hardly believe without the testimony of his own eyes and ears, how chastity is laughed at among them...?

He goes on to say that Italian men prefer not to get married in order to be at liberty to enjoy the favours of the renowned Italian courtesans. The married women and virgins, he claims, are locked up at home and wear veils when they go out. Since they have no conversation with men, he maintains, they will not miss the slightest opportunity to make cuckolds of their husbands, "though it be with the meanest servant."8 Here we find an echo of Portia's explanation for the Neapolitan's horse mania: "my lady his mother played false with a smith" (I.ii.42-3). The Neapolitan's portrait is smeared mainly because of over-indulgence in one skill or pleasure, considered as a deviation from the Renaissance civilised norm, which implied achievement of a Golden Mean through the avoidance of extremes and the practice of temperance.

\footnotetext{
${ }^{5}$ Quoted in William Shakespeare: The Merchant of Venice: Texts and Contexts, ed. M. Lindsay Kaplan (Boston: Bedford/St. Martin's, 2002), 129.

${ }^{6}$ Ibid., 129.

${ }^{7}$ Ibid., 167.

${ }^{8}$ Ibid., 168.
} 
It is interesting to compare the way in which the English were stereotyped by their continental neighbours. Italians and Germans alike accused them of being great lovers of themselves, and of having an antipathy to foreigners. During his stay in England between 1583 and 1585, the philosopher Giordano Bruno complained of being jostled and insulted. In 1586, George Pettie, a translator of Italian texts, lay the blame for such insults to the English on the influences which caused a change of behaviour in the English traveller when abroad. "England," he claimed, "is the civilest country in the worlde; and if it be thought to be otherwise by strangers, the disorders of those traveylers abrode are the chiefe cause of it." $"$

Although I realise an examination of the nature of the Jewish and Christian stereotypes in The Merchant of Venice would not be amiss, the space allotted here disallows a fuller account, therefore I will limit my investigation to the Italian and Spanish stereotypes.

Up to the $1570 \mathrm{~s}$, the Italian peninsula was seen by natives and visitors alike mainly through the differing features of the independent states that comprised it. From the $1570 \mathrm{~s}$ onward, generalized characterizations of Italians became common. When "Milan the Great" and "Naples the Noble" were under Spanish control and "Genoa the Proud" and "Florence the Fair" were tied to Spanish political aims, the peninsula was seen to be more homogenous. Only Venice remained separate, retaining her independence from Spanish power and resisting full commitment to the tight papal control of Catholic belief and organization that characterized the mid-sixteenth century CounterReformation. Italy became for outsiders politically and religiously one, the incorporated ally of Spain — in other words, England's, France's and the Netherlands' chief enemy. ${ }^{10}$ This new status provided material for traditional insult.

Although Italy had been the instigator of revived interest in classical antiquity, by the end of the sixteenth century Italomania was turning into Italophobia. ${ }^{11}$ The success of Italian manners had had a boomerang effect: hostility and mistrust of Italian cultural imperialism came to the fore in England and France, and elsewhere in Europe, and

\footnotetext{
${ }^{9}$ See J. Hale, op. cit., 63.

10 Ibid., 61-62.

${ }^{11}$ See P. Burke, op. cit., 207-210.
} 
feelings of cultural inferiority are to be detected in the stereotypes and caricatures centring on the Italians and the Italianised.

In 1600, an English translator of Livy, Philemon Holland, warned his readers that they should not visit the Italy described by the Roman author "so farre degenerate are the inhabitants now from the auncient people, so devoute, so virtuous and uncorrupt in old time." Here, as John Hale ${ }^{12}$ points out, he is echoing the opinion expressed thirty years earlier by Roger Ascham in The Scholemaster, and the famous warning he gave that an Italianate Englishman is a devil made flesh. This phrase was also common in Germany where the Italianate German was "demonised" in the same terms.

There was a tendency to compare the Italians to the decadent Greeks, and rivalry between the men of letters of Europe gave rise to an anti-Italian tone in many literary works of the Northern countries. ${ }^{13}$ Erasmus claimed that Latin literature was being supplanted by that of the Northern countries and in England the Italian theatre was criticised, even though sixteenth and seventeenth century English playwrights ransacked the Italian literature for materials. In his dedication to his own play Promos and Cassandra (1578), George Whetstone refers to the Italian player as being "so lascivious in his comedies that honest hearers are greeved at his actions". ${ }^{14}$ Thomas Nashe writes in Pierce Penniless His Supplication to the Devil: "Our players are not as the players beyond sea - a sort of squirting bawdy comedies that have whores and common courtesans to play women's parts, and forbear no immodest speech or unchaste action that may procure laughter." 15

There is no hint of the pot calling the kettle black here, no qualms about the somewhat problematic and eccentric use of transvestite boys on the English stage. Only the viciousness of the foreign stage is called into question, and English Renaissance culture shows no morbid fear of homoeroticism, but instead a more accurate fear of losing control of their women's chastity through their acting on

\footnotetext{
12 J. Hale, op. cit., 60.

13 See P. Burke, op. cit., 115-123.

14 George Whetstone, Promos and Cassandra, "Dedication to William Fleetewoode" (1578) in Norbert Platz, English Dramatic Theories, vol. 1. From Elyot to the Age of Dryden, 15311668 (Tübingen: Max Niemeyer Velag, 1973), 17.

15 Thomas Nashe, Pierce Penniless his Supplication to the Devil, in Thomas Nashe, vol. 1, ed. Stanley Wells (London: Edward Arnold, 1964), 66.
} 
the public stage. The prohibited aspects of homosocial behaviour are seen to be deflected onto women and onto Italians, and foreigners in general. Stereotyping represents a way for individuals of one group to assign to an Other a model of behaviour that they consider different from their own in order to guarantee and ensure allegiance to their own society. Elizabethan theatre, as Stephen Orgel has pointed out, is very much dependent on otherness: "Comedies are Italian, French or provincial, tragedies Spanish or Scandinavian or ancient: pastorals programmatically take place Somewhere Else."16 Displacement achieves a distancing effect which makes the plays more acceptable to the censor.

In The Place of the Stage: Licence, Play and Power in Renaissance England, Steve Mullaney quotes a certain Thomas Platter who wrote, after visiting London and its theatres in 1599, that he noticed the English passed their time "learning from plays what is happening in other lands; indeed men and women visit such places without scruple since the English do not travel much, but prefer to learn of strange things and take their pleasures at home." 17 The foreign settings and displacement of eccentricity were not intended merely to satisfy curiosity. On occasion, the continent was staged in order to be held up as a mirror to English audiences. Thomas Lodge's and Robert Greene's Ninevah-based A Looking Glasse for London and England of 1594 has an explicit mirror function. The image of continental alterity is re-defined by the dramatists as English identity on this analogical stage of the late morality tradition. Several exempla are performed, followed by moralizing prophet- and angel-characters who point out the self-reflexive nature of the stereotypical scenes in which adultery, poisoning, usury, treachery, the breaking of filial bonds are displayed in foreign lands and courts and then related to life in the London of the day. The prophet-figure Jonas steps forward at the close of the play to make the displacement principle, that works throughout the play, even clearer to the audience:

O London, maiden of the mistress-isle,

Wrapt in the folds and swathing-clouds of shame,

\footnotetext{
${ }^{16}$ Stephen Orgel, Impersonations: the Performance of Gender in Shakespeare's England (Cambridge: C.U.P., 1996), 12.

${ }^{17}$ Steve Mullaney, The Place of the Stage: Licence, Play and Power in Renaissance England (Chicago: University of Chicago Press, 1988), 75.
} 
In thee more sins than Nineveh contains!

Contempt of God, despite of reverend age,

Neglect of law, desire to wrong the poor,

Corruption, whoredom, drunkenness, and pride,

Swoln are thy brows with impudence and shame,

O proud adulterous glory of the west!

Thy neighbours burn, yet dost them fear no fire; $\quad(1.2508-2516)^{18}$

The results of the research of Bruno Bettelheim ${ }^{19}$ may be helpful in explaining the reasons for the great number of anti-Spanish caricatures that are to be found in the literature of the period in question. According to Bettelheim, stereotyping can be seen as a rationalisation of aggression and as a process whereby aggressiveness may be discharged through the act of stereotyping which consequently reveals the nature of the anxiety underlying the resulting stereotype. Spain's conquests in Italy, its links through Charles v and the German Netherlands Hapsburg Empire, and the lead it took in representing the aggressive edge of revived, militant Catholicism provided Spain with an increased antagonistic presence in the mental constructs of Europeans, constructs which often took the form of anti-Spanish caricatures. The conquest of the Moorish kingdom of Granada in the late fifteenth century and the forcible conversion to Christianity of the Moriscos who chose to stay, the expulsion of nearly all Jews from the whole of Spain strengthened the native cult of racial purity, ${ }^{20}$ resulting in the consolidation outside Spain of what was seen as a chief indicator of the Spanish character, pride.

Furthermore, because the Germans were particularly insulted by Charles v's use of Spanish troops against the Protestant cities and princes of the Schmalkaldic League in 1547, around a basic charge of cruelty clustered accusations of sexual licence and attempts to pervert the native honesty and decency of the German people. The fact that the Spanish forces systematically ransacked the cities and scorched the earth of the rebellious provinces of the Netherlands, along with reports about Spain's treatment of prisoners in the Inquisitorial jails all helped spread belief in the instinctive cruelty of the Spanish character. In England, diatribes against the Spanish Inquisition, such as the Acts

\footnotetext{
18 Robert Greene and Thomas Lodge, A Looking Glasse for England, in Chief PreShakespearian Drama, ed. Joseph Quincey Adams (Cambridge: Riverside, 1924), 146-147.

${ }^{19}$ B. Bettelheim and M. Janowitz, Social Change and Prejudice, Including Dynamics of Prejudice (New York: Free Press of Glencoe, 1964).

20 J. Hale, op. cit., 64, 475-478.
} 
and Monuments (1570) of John Foxe, a Protestant activist, all intensified the anxiety caused by questions raised concerning freedom of religious belief, or conscience, and Catholic persecution of Protestants. Furthermore, the Spanish claim to the English throne, through Philip II, the former brother-in-law of Elizabeth who had served as co-regent of England with his wife Mary from 1553-58, fuelled hostility. Elizabeth had refused Philip's offer of marriage after Mary's death, and for the remainder of their respective reigns the rulers engaged in overt or covert battle over national, international and religious issues. The Pope had excommunicated Elizabeth in 1570 and posed a political threat to her reign by releasing her Catholic subjects from allegiance to her. Religious differences posed a political threat at home and abroad; English policy attempted to distinguish between Catholics who remained faithful to their queen, in spite of the Pope's excommunication of her, and those Roman Catholics who sought to foment treason against England by joining with her enemies.

In The Merchant of Venice, onomastics contributes to the shorthand of stereotyping the Spanish, the Prince of Arragon's name being conveniently close to the adjective "arrogant." The reason he gives for not choosing the gold casket is that he wishes not to be ranked amongst "the barbarous multitudes" (II.ix.33). He opens the silver one instead, after a lengthy speech on "honour" - which could have come straight out of a Spanish "honour play" of the kind that Lope de Vega was writing at the time - and expects to be rewarded for his selfattributed merits. The mirror held up to him is the "portrait of a blinking idiot" (II.ix.54), the deserts of a "deliberate fool" (II.ix.80) who places too high a value on his own deserving, as Portia points out. In Shakespeare's portrait of an ethnocentric stereotype we find an echo of the words of Claude Lévi-Strauss: "Le barbare, c'est d'abord l'homme qui croit à la barbarie." ${ }^{21}$ A tamed Arragon leaves the stage, containing his anger, like a dog with its tail between its hind legs.

Onomastics is again the shorthand used by Shakespeare to shape audience reception in Love's Labour's Lost. If the play were written in the aftermath of the great defeat of the Spanish fleet in 1588, a Spaniard would provide a natural comic butt for the play, and his name, Don Adriano de Armado, is a none too subtle recall of the defeated Armada. Armado pictures himself as a warlike hero

${ }^{21}$ Claude Lévi-Strauss, Race et Histoire, coll. Folio/ Essais (Paris: Denoël, 1987), 22. 
unmanned for love and orders Moth to give him examples of great men in love, implicitly comparing himself to the Hercules, Solomans and Samsons of the venerable past, and simultaneously exaggerating his own caricature. Armado is of course a character derived from the Commedia dell'Arte of the popular Italian stage. This character, a development from the Miles Gloriosus of Plautine comedy, had already been transformed in Italian comedy into a Spanish soldier of fortune, a familiar figure in Italy when much of it was garrisoned by Spanish armies. In Love's Labour's Lost, the Spaniard is the comic butt in what might be called a "charivari" that is designed to make an exhibition of the culprit who has violated the social norms and generated a good deal of anxiety in the process. Here the Spanish threat is temporarily removed in cathartic outbursts of laughter.

After Henry IV of France signed a peace treaty with Spain in May 1599, thereby isolating Protestant England to a certain extent, a series of plays appeared on the English stage transmitting and encouraging a "hysterical hatred of foreigners and stay-at-home politicians as in post-Armada jingoistic drama." 22 Although Archbishop Whitgift found it necessary to prohibit satirical plays in which state affairs were broached in only thinly disguised mythological analogies, Spain and her political manoeuvring, whether real or imaginary, her expansionist policy, her role in championing the Counter-Reformation continued to furnish the theatres with materials capable of satisfying a public who required what David Bevington calls "an inflexible set of attitudes including hostility to Spain and the Catholic Church."23 This hostility grew as the negotiations for a Spanish marriage for Charles, the son of James I, brought the Spanish threat once again to the fore in England and initiated the destabilisation of the Stuart monarchy.

Thomas Middleton's A Game at Chess, which was put on at the open-air Globe in August 1624, played for a record run of nine days to packed houses before it was suppressed at the king's order. Unique in its boldness, the play appealed to an audience of mixed social status. Referred to in contemporary records as "our famous play of Gondomar," its main box-office attraction was the caricature of the widely hated Spanish ambassador, a smooth, witty dissembler,

\footnotetext{
22 David Bevington, Tudor Drama and Politics (Cambridge, Mass.: Harvard University Press, 1968), 290.

${ }^{23}$ Ibid., 288.
} 
popularly believed to have the ageing King James I under his thumb. The duplicity of the Spanish is greatly highlighted in the denouement with the disclosure of the foul play of the Spanish players whose real purpose was not to conclude a marriage agreement but to convert a heretical Protestant king and conquer his realm. Middleton's play, which abounds in routine anti-Spanish stereotypes, offers a highly mediated record of the period's perceptions of the Spanish. Such artistic perceptions of threats to a culture's frontiers reflect the deeply felt need for powerful, national self-assertion which is both inspired and necessitated by a foreign threat.

The playwrights and travelogues of Shakespeare's day played a role similar to that of the modern journalist. Members of an Elizabethan audience heard, like Ben Jonson's Justice Overdo "with other men's ears" and saw "with other men's eyes" (Bartholomew Fair, II.i.2728), ${ }^{24}$ and many of them, like Jonson's Princess Pecunia were willing to pay for news of "Any, any kind / So be it news, the newest that thou hast" (The Staple of News, III.ii.17-18). ${ }^{25}$ As theatres and newsbooks became profitable business, stereotyping was deliberately tailored to suit the tastes and prejudices of contemporary audiences and readers. Consequently, box-office considerations consciously and unconsciously helped form something like a secular public opinion and from the $1580 \mathrm{~s}$ onwards the commercial theatres, along with the pulpits of popular preachers and the cheap printing presses, became the equivalent to our mass media, produced under a general censorship which was almost exclusively political and religious. Simple-minded stereotypes developed into an awareness of the common good of the public weal, an approximation of the notion of nation.

Stereotypes may be attributed the same role as Marc Breitenberg (pace Freud) attributes to the notion of anxiety: "anxiety protects its subject as if it were a kind of psychic armour intended to safeguard the vulnerable ego within." 26 In the case of the stereotype, it is a psychic armour that distorts the truth, creating thereby a threat to

\footnotetext{
${ }^{24}$ Ben Jonson, Bartholomew Fair in Three Comedies, ed. Michael Jamieson (Harmondsworth: Penguin Books, 1981), 325-459.

${ }^{25}$ Ben Jonson, The Staple of News, ed. Anthony Parr, The Revels Plays (Manchester: Manchester University Press, 1999).

${ }^{26}$ Mark Breitenberg, Anxious Masculinity in Early Modern England (Cambridge: Cambridge University Press, 1996), 6.
} 
authentic communication between individuals. Stereotyping, whether on the stage or through the developing newsbook trade, may be seen as a prelude to the tabloid newspapers which today still represent a threat to genuine, civilised communication between differing cultures, between a superior "us" and that Other, "them."

Pauline BLANC

Université de Lyon III 